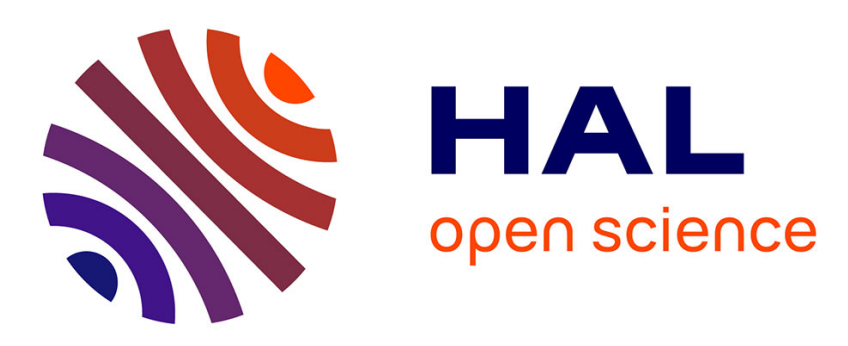

\title{
Portal myofibroblasts connect angiogenesis and fibrosis in liver
}

Sara Lemoinne, Dominique Thabut, Chantal Housset

\section{To cite this version:}

Sara Lemoinne, Dominique Thabut, Chantal Housset. Portal myofibroblasts connect angiogenesis and fibrosis in liver. Cell and Tissue Research, 2016, 365 (3), pp.583-589. 10.1007/s00441-016-2443-5 . hal-01338347

\section{HAL Id: hal-01338347 https://hal.sorbonne-universite.fr/hal-01338347}

Submitted on 28 Jun 2016

HAL is a multi-disciplinary open access archive for the deposit and dissemination of scientific research documents, whether they are published or not. The documents may come from teaching and research institutions in France or abroad, or from public or private research centers.
L'archive ouverte pluridisciplinaire HAL, est destinée au dépôt et à la diffusion de documents scientifiques de niveau recherche, publiés ou non, émanant des établissements d'enseignement et de recherche français ou étrangers, des laboratoires publics ou privés. 


\title{
Portal myofibroblasts connect angiogenesis and fibrosis in the liver
}

Sara Lemoinne ${ }^{1,2}$, Dominique Thabut ${ }^{1,3}$, Chantal Housset ${ }^{1,2}$

${ }^{1}$ Sorbonne Universités, UPMC Univ Paris 06, INSERM, UMR_S 938, Centre de Recherche Saint-Antoine (CRSA), Institute of Cardiometabolism and Nutrition (ICAN) Institut Hospitalo-Universitaire, F-75012 Paris, France;

${ }^{2}$ Assistance Publique-Hôpitaux de Paris (APHP), Hôpital Saint-Antoine, Centre de Référence Maladies Rares des Maladies Inflammatoires des Voies Biliaires, Service d'Hépatologie, F75012 Paris, France ;

${ }^{3}$ Assistance Publique-Hôpitaux de Paris (APHP), Hôpital Pitié-Salpétrière, Service d'HépatoGastroentérologie, F-75013 Paris, France.

\section{Correspondence to:}

Professor Chantal Housset, Faculté de Médecine \& Université Pierre et Marie Curie, Site Saint-Antoine, 27 rue Chaligny, 75571 Paris cedex 12, France.

Phone: (33) 140011359; Fax: (33) 140011488; E-mail: Chantal.Housset@inserm.fr

\begin{abstract}
Abbreviations : $\alpha$-SMA, alpha-smooth muscle actin; BDL, bile duct ligation; COX-2, cyclooxygenase-2; HSC, hepatic stellate cell; HSC-MF, hepatic stellate cell-derived myofibroblast; MCD, methionine-choline-deficient; MMP, matrix metalloproteinase; NAFLD, non-alcoholic fatty liver disease; PDGF-BB, platelet-derived growth factor-BB; PDGFR- $\beta$, platelet-derived growth factor receptor-beta; PIGF, placental growth factor; PMF, portal myofibroblast; TGF- $\beta$, transforming growth factor-beta; VEGF, vascular endothelial growth factor; VEGFR, vascular endothelial growth factor receptor.
\end{abstract}

\begin{abstract}
In all fibrotic tissues, the extracellular matrix is produced by myofibroblasts usually characterized by de novo expression of alpha-smooth muscle actin ( $\alpha$-SMA). While in the liver, myofibroblasts mainly derive from hepatic stellate cells (HSCs), cells that are distinct from HSCs and located in the portal tract, can also give rise to myofibroblasts that we globally refer to as portal myofibroblasts (PMFs). By different mechanisms that include the formation of direct intercellular junctions with endothelial cells and the production of VEGFA-containing microparticles, PMFs promote angiogenesis which progresses in parallel with
\end{abstract}


fibrosis in response to inflammation and fibrosis, in the liver. Hepatic angiogenesis and fibrosis share many signaling pathways, which can be targeted by common therapies. Compared to HSC-MFs, PMFs overexpress COL15A1, which both stabilizes newly formed vessels and forms a scaffold for the deposition of interstitial collagen that accumulates in the fibrotic liver. Thereby, PMFs may provide a critical link between angiogenesis and fibrosis in livers diseases.

The incidence of chronic liver diseases keeps growing worldwide, largely due to the epidemic of the metabolic syndrome and non-alcoholic fatty liver disease (NAFLD). To a great extent, the prognosis of chronic liver diseases is determined by the development of liver fibrosis. However, no anti-fibrotic drug that would prevent the progression of liver fibrosis towards cirrhosis, is yet available and a better understanding of fibrogenesis in the liver is still needed. Liver fibrogenesis is a dynamic process including quantitative and qualitative changes of the extracellular matrix, of which the most prominent is the deposition of type I collagen. These changes progressively disrupt normal liver architecture and result in cirrhosis formation. In the fibrotic liver, like in all other fibrotic tissues, the extracellular matrix is produced by cells usually characterized by de novo expression of alpha-smooth muscle actin ( $\alpha$-SMA), known as myofibroblasts.

\section{Liver myofibroblasts}

Myofibroblasts form heterogeneous populations of cells, with different possible origins. Current evidence indicates that in the liver, myofibroblasts mainly derive from hepatic stellate cells (HSCs) (Mederacke, et al., 2013). However, cells that are distinct from HSCs and located in the portal tract, can also give rise to myofibroblasts that we now globally refer to as portal myofibroblasts (PMFs) (Lemoinne, et al., 2015, Lua, et al., 2016). PMFs were first described in the setting of biliary-type liver fibrosis, such as that induced by bile duct ligation (BDL) in rats or mice (Kinnman, et al., 2003). PMFs outnumber hepatic stellate cell-derived myofibroblasts (HSC-MFs) at the onset of biliary-type liver injury (Beaussier, et al., 2007), contributing for more than $70 \%$ to liver myofibroblasts, five days after BDL (Iwaisako, et al., 2014). Simultaneously in sinusoids, HSCs undergo phenotypic changes including the overexpression of desmin and of platelet-derived growth factor receptor-beta (PDGFR- $\beta$ ) as well as increased DNA synthesis, yet without fully converting into myofibroblasts, at this stage (Beaussier, et al., 2007). Studies of PMFs in culture demonstrated that they required transforming growth factor-beta (TGF- $\beta$ ) and that they were also dependent on mechanical 
tension, for myofibroblastic differentiation (Li, et al., 2007), a typical feature of myofibroblasts (Eyden, 2008). In vivo, the emergence and expansion of PMFs can be triggered by interactions with ductular epithelial cells, which proliferate after bile duct injury in the so-called ductular reaction. Thus, a marked increase in the expression of $\alpha v \beta 6$ integrin on the surface of ductular epithelial cells is induced by acute bile duct obstruction in mice, which directly triggers periductal accumulation of myofibroblasts and fibrosis, through the activation of TGF- $\beta$ (Wang, et al., 2007). In human liver tissues, the expression of $\alpha \mathrm{v} \beta 6$ in ductular epithelial cells, was also found to be increased in acute, but not chronic, biliary-type injury (Wang, et al., 2007). Reactive ductules also express profibrogenic factors such as TGF$\beta$ itself or platelet-derived growth factor-BB (PDGF-BB), which also stimulates PMF expansion (Kinnman, et al., 2003). Yet, the biology of PMFs remains poorly known, mainly due to the lack of markers that would allow investigators to authenticate and distinguish them from HSC-MFs, in the injured liver. In a majority of studies, HSC-MFs have been identified on the unique basis of $\alpha$-SMA expression, one of the many markers they have in common with PMFs. Therefore, the contribution of PMFs may have been underestimated, and some of their properties improperly allocated to HSC-MFs. By comparing the transcriptome of PMFs and HSC-MFs, we identified a marker of PMFs, virtually not expressed in HSC-MFs nor in any other liver cell type, i.e. collagen, type XV, alpha1 (COL15A1) (Lemoinne, et al., 2015), and this result was subsequently confirmed by another group (Lua, et al., J Hepatol 2016). We showed that both in animal models and in patients with chronic liver diseases, a marked increase in the hepatic expression of COL15A1 occurred at the time of progression to advanced liver fibrosis (Lemoinne, et al., 2015). This was the case not only in biliary-type liver fibrosis (i.e. bile duct-ligated rats and patients with primary biliary cholangitis) but also in post-necrotic liver fibrosis (i.e. carbon tetrachloride-treated rats and patients with NAFLD), suggesting that PMFs or at least sub-populations of PMFs were implicated in the progression of all types of liver fibrosis. Besides $\alpha$-SMA expression, myofibroblasts are characterized by ultrastructural features, including a prominent rough endoplasmic reticulum, a Golgi apparatus producing collagen secretory granules and peripheral myofilaments (Eyden, 2008). Yet another highly characteristic trait, is a cell-to-matrix junction, consisting of an aligned myofilament bundle and fibronectin fibril contacting one another through a point at the cell surface, termed fibronexus (Eyden, 2008). Of particular interest in this respect, we found in our previous comparative analyses that PMFs compared to HSC-MFs expressed fibronectin at higher levels and virtually no desmin, that both belong to the definition of myofibroblasts (Eyden, 2008). Therefore, PMFs fulfill more criteria that define myofibroblasts than HSC- 
MFs do (Eyden, 2008).

\section{Liver angiogenesis}

Angiogenesis is a dynamic process leading to the formation of news vessels from preexisting vessels. In all tissues, angiogenesis is determined by two main pathways, i.e. hypoxia and inflammation, and comprises the following steps: i) sprouting and budding of endothelial cells; ii) degradation of the extracellular matrix by proteinases and migration of endothelial cells; iii) endothelial cell proliferation, tube formation and branching; iv) vessel maintenance, maturation and stabilization (Elpek, 2015). Vascular endothelial growth factor (VEGF) signaling is implicated in virtually all steps of angiogenesis, while the recruitment of mural pericyte-like cells is required in the last step, for nascent vessels to mature and stabilize. It is now well established that liver disease progression is accompanied by angiogenesis. The first demonstration was provided more than thirty years ago by Rappaport et al., who showed that human cirrhotic livers contained more vessels than healthy livers, and that cirrhotic nodules were surrounded by a dense vascular plexus (Rappaport, et al., 1983). Liver tissue hypoxia occurs at early stages of liver injury and increases with disease progression, as a result of structural and functional changes in the liver angioarchitecture (Corpechot, et al., 2002). During liver fibrogenesis, fibrillar type I collagen progressively replaces type IV collagen in the perisinusoidal space of Disse, which together with the loss of endothelial fenestrations, causes sinusoidal capillarization. Therefore, fibrosis by itself can contribute to the development of hypoxia, and thereby promote angiogenesis. Vascular remodeling leading to capillarization of the sinusoids and generation of intrahepatic shunts characterizes hepatic angiogenesis. Such changes in angioarchitecture cause a decrease in hepatocyte perfusion, that aggravates hypoxia. Liver angiogenesis is also stimulated by inflammation. Chemokinedependent accumulation of monocyte-derived macrophages is an important mechanism of hepatic inflammation and fibrogenesis, in human liver diseases and experimental mouse models. The chemokine receptor CCR2 and its ligand CCL2 (MCP-1) promote the accumulation of monocyte-derived macrophages releasing pro-inflammatory and proangiogenic cytokines in the liver. Infiltrating CCL2-dependent inflammatory monocytes also provide pro-angiogenic signals, via the production of VEGF-A and matrix metalloproteinase (MMP)-9 (Ehling, et al., 2014). Three-dimensional micromorphological analyses in mouse models of carbon tetrachloride- or bile duct ligation-induced liver injury, demonstrated that macrophage-dependent angiogenesis during chronic liver injury was largely confined to portal veins and that pharmacological inhibition of CCL2-mediated inflammatory monocyte 
infiltration primarily reduced angiogenic vessel sprouting in the portal vein (Ehling, et al., 2014). Therefore, infiltrating bone marrow-derived inflammatory monocytes would mediate the induction of hepatic angiogenesis by effects that are primarily attributable to changes in the portal vein system.

Angiogenesis and fibrosis progression closely correlate in experimental liver injury and human liver disease. Angiogenesis and fibrogenesis are also triggered by similar pathways in response to hypoxia and inflammation, so that a potential causal relationship between them has been difficult to establish. In fact, dichotomous effects of angiogenesis on fibrosis have now been reported, in different tissues. The administration of VEGF, while stimulating angiogenesis, has been shown to reduce renal fibrosis and to stabilize renal function, in the remnant kidney model of progressive renal failure (Kang, et al., 2001). Proangiogenic activity induced in an adipocyte-specific VEGF-A overexpression model, has shown to suppress fibrosis, inflammation and insuline resistance during the early phase of high fat diet-induced adipose tissue expansion. Conversely, VEGF-A-VEGFR2 blockade had an aggravating effect in this context, whereas in $o b / o b$ mice with preexisting adipose tissue dysfunction, the antiangiogenic action of VEGF-A-VEGFR2 blockade caused an improvement in metabolism and a decrease in inflammatory factors (Sun, et al., 2012). A large number of studies in animal models of liver injury showed that the inhibition of angiogenesis led to a decrease in liver fibrosis (Table 1). However, the pathways targeted in these studies, could have also promoted fibrosis, directly. In addition, a few studies led to different conclusions. Thus, pharmacological inhibition of the vitronectin receptor integrin alphavbeta3 which stimulates endothelial cell proliferation and HSC activation, while suppressing hepatic angiogenesis, aggravated liver fibrosis induced by BDL or thioacetamide (Patsenker, et al., 2009). Pharmacological inhibition of the chemokine CCL2 reduced monocyte infiltration and angiogenesis but not fibrosis progression in mouse models of carbon tetrachloride or BDLinduced liver injury (Ehling, et al., 2014). Dichotomous effects of angiogenesis were also reported in a model of fibrosis resolution generated by cholecystojejunostomy that restored bile flow after BDL (Yang, et al., 2014a). In this model, VEGF-induced angiogenesis promoted fibrogenesis after bile duct ligation but was also required for fibrosis resolution after cholecystojejunostomy. Accordingly, VEGF-neutralizing antibodies prevented the development of fibrosis but also disrupted hepatic tissue repair and fibrosis resolution (Yang, et al., 2014a).

Contribution of portal myofibroblasts to liver angiogenesis 
HSC-MFs and PMFs likely both contribute to liver angiogenesis, although at different stages. HSCs in their quiescent state, act as pericytes that regulate the functions of sinusoidal endothelial cells. Following myofibroblastic differentiation, they acquire a proangiogenic phenotype and secrete proangiogenic factors such as angiopoietin-1 (Semela, et al., 2008, Thabut, et al., 2011). At an early stage of liver injury, HSC-MFs promote enhanced coverage of sinusoids and angiogenesis in areas of active fibrogenesis at the leading edge of developing fibrotic septa (Novo, et al., 2007). At later stages, endothelial cell proliferation correlate with the expansion of PMFs, which has suggested a role of PMF in liver angiogenesis (Lemoinne, et al., 2015). Further evidence that this was the case, was provided by the immunostaining of human cirrhotic livers showing that COL15A1-positive PMFs displayed a perivascular distribution and outlined vascular capillaries within large fibrotic septa. Using a cell model of PMFs that we previously described in detail, we demonstrated that PMFs were able to enhance angiogenesis in vitro and in vivo, by different mechanisms including the formation of direct intercellular junctions with endothelial cells and the production of VEGF-A-containing microparticles (Lemoinne, et al., 2015). Compared to HSC-MFs, PMFs largely overexpress COL15A1 and also COL18A1, which are the $\alpha 1$ chains of collagen XV and collagen XVIII, respectively. Both collagens belong to the superfamily of multiplexins and their C-terminal parts, endostatin and restin, respectively are anti-angiogenic, which could provide a negative retrocontrol in PMF-induced angiogenesis. Collagen XV provides stability and resilience to mechanical forces in the skeletal muscle and microvessels. It is contained in the basement membrane of continuous capillaries, serving as a scaffold that anchors the basement membrane to interstitial collagen, and loss of its expression results in collapsed capillaries in mice. It is absent from specialized capillaries like fenestrated liver sinusoids, and the normal liver contains almost no collagen $\mathrm{XV}$, with the exception of trace amounts in the portal and periportal area. Collagen XV forms a proangiogenic matrix for endothelial cells, and thereby could contribute to the angiogenic properties of PMFs. Increased expression of collagen XV has been reported in hepatocellular carcinogenesis in mice and humans. In human hepatocellular carcinoma, collagen XV was identified as a prominent histopathological component of intratumoral capillaries (Kimura, et al., 2016).

In summary, PMFs appear to be critical in pathological angiogenesis, which constantly occurs in advanced liver fibrosis. While it remains to be elucidated how angiogenesis and fibrosis are linked to each other during the progression of liver diseases, we suggest that COL15A1- 
producing PMFs could provide an important link by both stabilizing newly formed vessels and forming a scaffold for the deposition of interstitial collagen (Figure 1).

\section{References}

Beaussier M, Wendum D, Schiffer E, Dumont S, Rey C, Lienhart A, Housset C (2007) Prominent contribution of portal mesenchymal cells to liver fibrosis in ischemic and obstructive cholestatic injuries. Lab Invest 87:292-303

Corpechot C, Barbu V, Wendum D, Kinnman N, Rey C, Poupon R, Housset C, Rosmorduc O (2002) Hypoxia-induced VEGF and collagen I expressions are associated with angiogenesis and fibrogenesis in experimental cirrhosis. Hepatology 35:1010-1021

Ehling J, Bartneck M, Wei X, Gremse F, Fech V, Mockel D, Baeck C, Hittatiya K, Eulberg D, Luedde T, Kiessling F, Trautwein C, Lammers T, Tacke F (2014) CCL2-dependent infiltrating macrophages promote angiogenesis in progressive liver fibrosis. Gut 63:1960-1971

Elpek GO (2015) Angiogenesis and liver fibrosis. World J Hepatol 7:377-391

Eyden B (2008) The myofibroblast: phenotypic characterization as a prerequisite to understanding its functions in translational medicine. J Cell Mol Med 12:22-37

Gao JH, Wen SL, Yang WJ, Lu YY, Tong H, Huang ZY, Liu ZX, Tang CW (2013) Celecoxib ameliorates portal hypertension of the cirrhotic rats through the dual inhibitory effects on the intrahepatic fibrosis and angiogenesis. PloS one 8:e69309

Hennenberg M, Trebicka J, Kohistani Z, Stark C, Nischalke HD, Kramer B, Korner C, Klein S, Granzow M, Fischer HP, Heller J, Sauerbruch T (2011) Hepatic and HSC-specific sorafenib effects in rats with established secondary biliary cirrhosis. Lab Invest 91:241-251

Huang Y, Feng H, Kan T, Huang B, Zhang M, Li Y, Shi C, Wu M, Luo Y, Yang J, Xu F (2013) Bevacizumab attenuates hepatic fibrosis in rats by inhibiting activation of hepatic stellate cells. PloS one 8:e73492

Iwaisako K, Jiang C, Zhang M, Cong M, Moore-Morris TJ, Park TJ, Liu X, Xu J, Wang P, Paik YH, Meng F, Asagiri M, Murray LA, Hofmann AF, Iida T, Glass CK, Brenner DA, Kisseleva T (2014) Origin of myofibroblasts in the fibrotic liver in mice. Proc Natl Acad Sci U S A 111:E3297-3305

Kang DH, Hughes J, Mazzali M, Schreiner GF, Johnson RJ (2001) Impaired angiogenesis in the remnant kidney model: II. Vascular endothelial growth factor administration reduces renal fibrosis and stabilizes renal function. J Am Soc Nephrol 12:1448-1457

Kimura K, Nakayama M, Naito I, Komiyama T, Ichimura K, Asano H, Tsukuda K, Ohtsuka A, Oohashi T, Miyoshi S, Ninomiya Y (2016) Human collagen XV is a prominent histopathological component of sinusoidal capillarization in hepatocellular carcinogenesis. Int J Clin Oncol 21:302-309

Kinnman N, Francoz C, Barbu V, Wendum D, Rey C, Hultcrantz R, Poupon R, Housset C (2003) The myofibroblastic conversion of peribiliary fibrogenic cells distinct from hepatic stellate cells is stimulated by platelet-derived growth factor during liver fibrogenesis. Lab Invest 83:163-173

Lemoinne S, Cadoret A, Rautou PE, El Mourabit H, Ratziu V, Corpechot C, Rey C, Bosselut N, Barbu V, Wendum D, Feldmann G, Boulanger C, Henegar C, Housset C, Thabut D (2015) Portal myofibroblasts promote vascular remodeling underlying cirrhosis formation through the release of microparticles. Hepatology 61:1041-1055 
Li Z, Dranoff JA, Chan EP, Uemura M, Sevigny J, Wells RG (2007) Transforming growth factor-beta and substrate stiffness regulate portal fibroblast activation in culture. Hepatology 46:1246-1256

Liu C, Yang Z, Wang L, Lu Y, Tang B, Miao H, Xu Q, Chen X (2015) Combination of sorafenib and gadolinium chloride $(\mathrm{GdCl} 3)$ attenuates dimethylnitrosamine(DMN)induced liver fibrosis in rats. BMC Gastroenterol 15:159

Lua I, Li Y, Zagory JA, Wang KS, French SW, Sevigny J, Asahina K (2016) Characterization of hepatic stellate cells, portal fibroblasts, and mesothelial cells in normal and fibrotic livers. J Hepatol 64:1137-1146

May D, Djonov V, Zamir G, Bala M, Safadi R, Sklair-Levy M, Keshet E (2011) A transgenic model for conditional induction and rescue of portal hypertension reveals a role of VEGF-mediated regulation of sinusoidal fenestrations. PloS one 6:e21478

Mederacke I, Hsu CC, Troeger JS, Huebener P, Mu X, Dapito DH, Pradere JP, Schwabe RF (2013) Fate tracing reveals hepatic stellate cells as dominant contributors to liver fibrosis independent of its aetiology. Nat Commun 4:2823

Mejias M, Garcia-Pras E, Tiani C, Miquel R, Bosch J, Fernandez M (2009) Beneficial effects of sorafenib on splanchnic, intrahepatic, and portocollateral circulations in portal hypertensive and cirrhotic rats. Hepatology 49:1245-1256

Novo E, Cannito S, Zamara E, Valfre di Bonzo L, Caligiuri A, Cravanzola C, Compagnone A, Colombatto S, Marra F, Pinzani M, Parola M (2007) Proangiogenic cytokines as hypoxia-dependent factors stimulating migration of human hepatic stellate cells. The American journal of pathology 170:1942-1953

Patsenker E, Popov Y, Stickel F, Schneider V, Ledermann M, Sagesser H, Niedobitek G, Goodman SL, Schuppan D (2009) Pharmacological inhibition of integrin alphavbeta3 aggravates experimental liver fibrosis and suppresses hepatic angiogenesis. Hepatology 50:1501-1511

Rappaport AM, MacPhee PJ, Fisher MM, Phillips MJ (1983) The scarring of the liver acini (Cirrhosis). Tridimensional and microcirculatory considerations. Virchows Arch A Pathol Anat Histopathol 402:107-137

Sahin H, Borkham-Kamphorst E, Kuppe C, Zaldivar MM, Grouls C, Al-samman M, Nellen A, Schmitz P, Heinrichs D, Berres ML, Doleschel D, Scholten D, Weiskirchen R, Moeller MJ, Kiessling F, Trautwein C, Wasmuth HE (2012) Chemokine Cxc19 attenuates liver fibrosis-associated angiogenesis in mice. Hepatology 55:1610-1619

Semela D, Das A, Langer D, Kang N, Leof E, Shah V (2008) Platelet-derived growth factor signaling through ephrin-b2 regulates hepatic vascular structure and function. Gastroenterology 135:671-679

Sun K, Wernstedt Asterholm I, Kusminski CM, Bueno AC, Wang ZV, Pollard JW, Brekken RA, Scherer PE (2012) Dichotomous effects of VEGF-A on adipose tissue dysfunction. Proc Natl Acad Sci U S A 109:5874-5879

Taura K, De Minicis S, Seki E, Hatano E, Iwaisako K, Osterreicher CH, Kodama Y, Miura K, Ikai I, Uemoto S, Brenner DA (2008) Hepatic stellate cells secrete angiopoietin 1 that induces angiogenesis in liver fibrosis. Gastroenterology 135:1729-1738

Thabut D, Routray C, Lomberk G, Shergill U, Glaser K, Huebert R, Patel L, Masyuk T, Blechacz B, Vercnocke A, Ritman E, Ehman R, Urrutia R, Shah V (2011) Complementary vascular and matrix regulatory pathways underlie the beneficial mechanism of action of sorafenib in liver fibrosis. Hepatology

Tugues S, Fernandez-Varo G, Munoz-Luque J, Ros J, Arroyo V, Rodes J, Friedman SL, Carmeliet P, Jimenez W, Morales-Ruiz M (2007) Antiangiogenic treatment with sunitinib ameliorates inflammatory infiltrate, fibrosis, and portal pressure in cirrhotic rats. Hepatology 46:1919-1926 
Van Steenkiste C, Ribera J, Geerts A, Pauta M, Tugues S, Casteleyn C, Libbrecht L, Olievier K, Schroyen B, Reynaert H, van Grunsven LA, Blomme B, Coulon S, Heindryckx F, De Vos M, Stassen JM, Vinckier S, Altamirano J, Bataller R, Carmeliet P, Van Vlierberghe H, Colle I, Morales-Ruiz M (2011) Inhibition of placental growth factor activity reduces the severity of fibrosis, inflammation, and portal hypertension in cirrhotic mice. Hepatology 53:1629-1640

Wang B, Dolinski BM, Kikuchi N, Leone DR, Peters MG, Weinreb PH, Violette SM, Bissell DM (2007) Role of alphavbeta6 integrin in acute biliary fibrosis. Hepatology 46:14041412

Yan Z, Qu K, Zhang J, Huang Q, Qu P, Xu X, Yuan P, Huang X, Shao Y, Liu C, Zhang H, Xing J (2015) CD147 promotes liver fibrosis progression via VEGF-A/VEGFR2 signalling-mediated cross-talk between hepatocytes and sinusoidal endothelial cells. Clin Sci (Lond) 129:699-710

Yang L, Kwon J, Popov Y, Gajdos GB, Ordog T, Brekken RA, Mukhopadhyay D, Schuppan D, Bi Y, Simonetto D, Shah VH (2014a) Vascular endothelial growth factor promotes fibrosis resolution and repair in mice. Gastroenterology 146:1339-1350 e1331

Yang YY, Liu RS, Lee PC, Yeh YC, Huang YT, Lee WP, Lee KC, Hsieh YC, Lee FY, Tan TW, Lin HC (2014b) Anti-VEGFR agents ameliorate hepatic venous dysregulation/microcirculatory dysfunction, splanchnic venous pooling and ascites of NASH-cirrhotic rat. Liver Int 34:521-534

Yoshiji H, Kuriyama S, Yoshii J, Ikenaka Y, Noguchi R, Hicklin DJ, Wu Y, Yanase K, Namisaki T, Yamazaki M, Tsujinoue H, Imazu H, Masaki T, Fukui H (2003) Vascular endothelial growth factor and receptor interaction is a prerequisite for murine hepatic fibrogenesis. Gut 52:1347-1354

\section{Figure legend}

Figure 1. Role of portal myofibroblasts in liver angiogenesis and fibrosis.

A) In normal liver, quiescent hepatic stellate cells (HSCs) for a continuum with portal mesenchymal cells, which include vascular smooth muscle cells (SMCs), portal fibroblasts and few mesenchymal progenitor cells. The extracellular matrix is poorly abundant and contains trace amounts of COL15A1 along mesenchymal progenitors. B) In advanced fibrosis, portal myofibroblasts (PMFs) proliferate and promote angiogenesis. COL15A1 expressed by PMFs provides a scaffold for interstitial collagen produced in excess mostly by hepatic stellate cell-derived myofibroblats (HSC-MFs). 
Table 1. Effects of angiogenesis inhibition on liver fibrosis in experimental models

\begin{tabular}{|c|c|c|c|}
\hline Reference & Animal model & $\begin{array}{c}\text { Anti-angiogenic } \\
\text { treatment }\end{array}$ & $\begin{array}{l}\text { Assay and change in } \\
\text { liver fibrosis }\end{array}$ \\
\hline (Yoshiji, et al., 2003) & Mouse $-\mathrm{CCl}_{4}$ & $\begin{array}{l}\text { Anti-VEGFR-1 Ab } \\
\text { Anti-VEGFR-2 Ab }\end{array}$ & $\begin{array}{l}\text { Hydroxyproline } \\
(\mathbf{y})\end{array}$ \\
\hline (Tugues, et al., 2007) & Rat $-\mathrm{CCl}_{4}$ & $\begin{array}{l}\text { Sunitinib (multiple } \\
\text { TK inhibitor) }\end{array}$ & $\begin{array}{l}\text { Masson trichrome } \\
\text { staining }(\boldsymbol{y})\end{array}$ \\
\hline (Taura, et al., 2008) & Mouse - $\mathrm{CCl}_{4}, \mathrm{BDL}$ & $\begin{array}{l}\text { Blockade of } \\
\text { angiopoietin } \\
\text { signaling by } \\
\text { AdsTie2 }\end{array}$ & $\begin{array}{l}\text { Hydroxyproline, } \\
\text { Sirius red staining } \\
\text { (y) }\end{array}$ \\
\hline (Mejias, et al., 2009) & Rat - BDL & $\begin{array}{l}\text { Sorafenib (multiple } \\
\text { TK inhibitor) }\end{array}$ & $\begin{array}{l}\text { Sirius red staining } \\
(\mathbf{y})\end{array}$ \\
\hline (Patsenker, et al., 2009) & Rat - BDL, TAA & $\begin{array}{l}\text { Cilenglinide } \\
\text { ( } \alpha \mathrm{v} \beta 3 / \alpha v \beta 5 \text { integrin } \\
\text { inhibitor) }\end{array}$ & $\begin{array}{l}\text { Hydroxyproline, } \\
\text { Sirius red staining } \\
(\boldsymbol{\pi})\end{array}$ \\
\hline (Thabut, et al., 2011) & Rat - BDL & Sorafenib & $\begin{array}{l}\text { Magnetic resonance } \\
\text { elastography, } \\
\text { Sirius red staining } \\
(\mathbf{y})\end{array}$ \\
\hline $\begin{array}{l}\text { (Van Steenkiste, et al., } \\
\text { 2011) }\end{array}$ & Mouse $-\mathrm{CCl}_{4}$ & Anti-PlGF Ab & $\begin{array}{l}\text { Sirius red staining } \\
(\boldsymbol{y})\end{array}$ \\
\hline $\begin{array}{l}\text { Hennenberg et al. } 2011 \\
\text { (Hennenberg, et al., 2011) }\end{array}$ & Rat - BDL & Sorafenib & $\begin{array}{l}\text { Sirius red staining } \\
(\boldsymbol{y})\end{array}$ \\
\hline $\begin{array}{l}\text { May et al. } 2011 \text { (May, et } \\
\text { al., 2011) }\end{array}$ & Mouse & $\begin{array}{l}\text { Blockade of VEGF } \\
\text { signaling by } \\
\text { transgenic } \\
\text { conditional } \\
\text { induction of a VEGF } \\
\text { decoy receptor }\end{array}$ & $\begin{array}{l}\text { Goldner staining } \\
(\boldsymbol{\pi})\end{array}$ \\
\hline (Sahin, et al., 2012) & Mouse - $\mathrm{CCl}_{4}$ & $\begin{array}{l}\mathrm{CxCl9} \text { (angiostatic } \\
\text { chemokine) }\end{array}$ & $\begin{array}{l}\text { Hydroxyproline, } \\
\text { Sirius red staining } \\
(\boldsymbol{y})\end{array}$ \\
\hline (Huang, et al., 2013) & Rat $-\mathrm{CCL}_{4}$ & $\begin{array}{l}\text { Bevacizumab (anti- } \\
\text { VEGF } \mathrm{Ab} \text { ) }\end{array}$ & $\begin{array}{l}\text { Hydroxyproline, } \\
\text { Sirius red staining } \\
(\mathbf{y})\end{array}$ \\
\hline (Gao, et al., 2013) & Rat - TAA & $\begin{array}{l}\text { Celecoxib } \\
\text { (COX-2 inhibitor) }\end{array}$ & $\begin{array}{l}\text { Masson trichrome } \\
\text { staining }(\boldsymbol{y})\end{array}$ \\
\hline (Yang, et al., 2014b) & Rat - High-fat/MCD & $\begin{array}{l}\text { Sorafenib, Brivanib } \\
\text { (muliple TK } \\
\text { inhibitors) }\end{array}$ & $\begin{array}{l}\text { Hydroxyproline } \\
(\mathbf{y})\end{array}$ \\
\hline (Yang, et al., 2014a) & $\begin{array}{l}\text { Mouse } \\
\text { - BDL } \\
\text { - BDL followed by } \\
\text { cholecystojejunostomy }\end{array}$ & ) Anti-VEGF Ab & $\begin{array}{l}\text { Hydroxyproline, } \\
\text { Sirius red staining } \\
(\boldsymbol{y}) \\
(\boldsymbol{\pi})\end{array}$ \\
\hline (Ehling, et al., 2014) & Mouse - $\mathrm{CCl}_{4}, \mathrm{BDL}$ & $\begin{array}{l}\mathrm{CCl} 2 \\
\text { pharmacological }\end{array}$ & $\begin{array}{l}\text { Sirius red staining } \\
(\rightarrow)\end{array}$ \\
\hline
\end{tabular}


AdsTie2, adenovirus expressing the extracellular domain of Tie2; PlGF, placental growth factor; COX-2, cyclooxygenase-2; MCD, methionine-choline-deficient. 
A

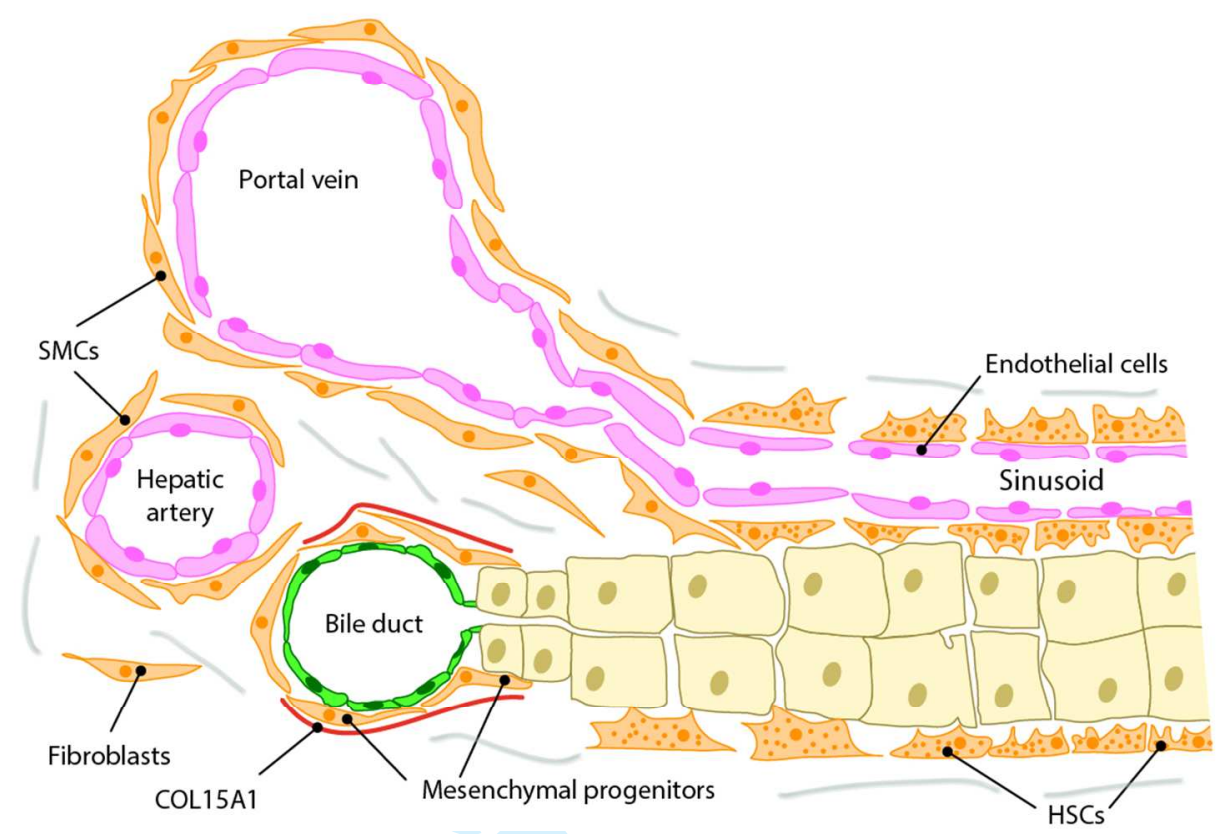

29

30

31

32

33

34

35

36

37

38

39

40

41

42

43

44

45

46

47

48

49

50

51

52

53

54

55

56

57

58

59

60 


\section{Page 13 of 13}

1
2
3
4
5
6
7
8
9
10
11
12
13
14
15
16
17
18
19
20
21
22
23
24
25
26
27
28
29
30
31
32
33
34
35
36
37
38
39
40
41
42
43
44
45
46
47
48
49
50
51
52
53
54
55
56
57
58
60

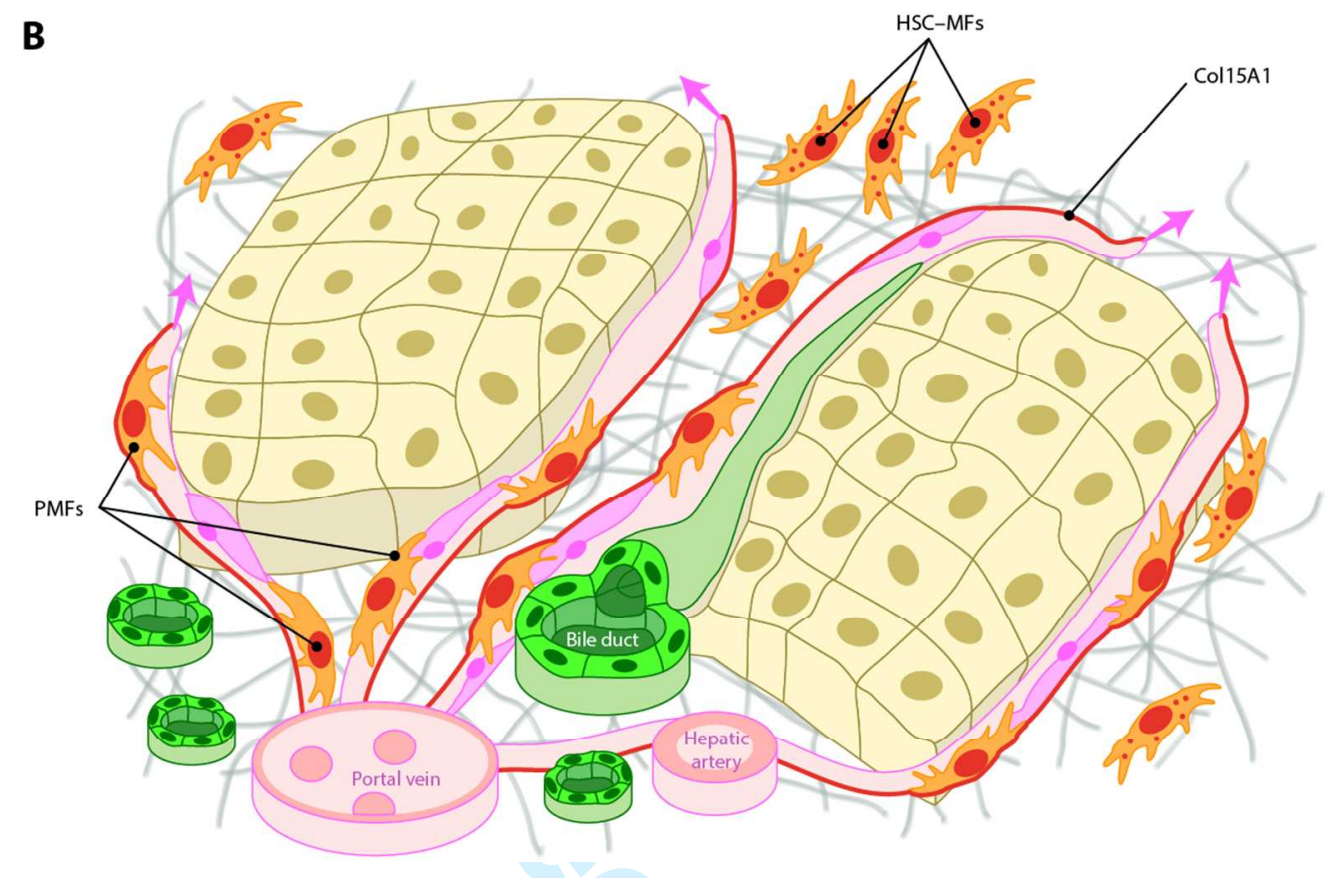

29

32

33

34

35

37

38

39

40

41

42

44

45

46

47

48

49

51

52

53

54

55

56

57

59

60

Cell and Tissue Research

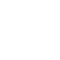

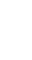

B

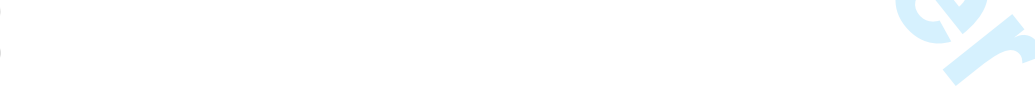

